\title{
Trauma in women of child-bearing age in a high-income developing country
}

\author{
Yüksek gelirli gelişmekte olan bir ülkede \\ çocuk doğurma yaşındaki kadınlarda travma
}

\author{
Alaa K. ABBAS, ${ }^{1}$ Hisham MIRGHANI, ${ }^{2}$ Hani O. EID, ${ }^{3}$ Fikri M. ABU-ZIDAN ${ }^{1}$
}

\section{BACKGROUND}

We aimed to study the distribution and causes of trauma in women of child-bearing age.

\section{METHODS}

Data were collected from Al-Ain Hospital (United Arab Emirates-UAE) Trauma Registry. Females aged 16 to 45 years (child-bearing age) who were admitted with trauma between March 2003 and March 2006 were included in the study.

\section{RESULTS}

Females represented $9 \%(n=171)$ of all trauma patients $(n=1809)$ of the same age group, of which $29 \%$ were UAE nationals. The mean age for females was 30.5 years. Road traffic collision (RTC) was the main mechanism of injury $(n=78,46 \%)$. Burns were significantly higher in females than males $(p=0.001)$. Cervical fractures were significantly higher in females $(p=0.04)$, while lumbar fractures were significantly higher in males $(p=0.03)$. In females, pelvic fractures were diagnosed in $6.4 \%$, spinal fractures in $7 \%$, and both injuries in $1.2 \%$. Three females died (1.7\%), and all were due to RTC.

\section{CONCLUSION}

The majority of females involved in trauma were aged 2034 years. RTC is the main mechanism of injury and fatality. Female trauma is associated with a high incidence of pelvic fractures. A higher rate of cervical injuries was observed in females in contrast to lumbar injuries in males.

Key Words: Women; child-bearing age; trauma.

\section{AMAC}

Çocuk doğurma çağında bulunan kadınlardaki travma ile ilgili dağılım ve nedenler araştırıldı.

\section{GEREÇ VE YÖNTEM}

$\mathrm{Bu}$ çalışmadaki veriler, Al-Ain Hastanesi (Birleşik Arap Emirlikleri-BAE) Travma Kayıtlarından derlendi. 16 ile 45 arası (çocuk doğurma çağı) bir yaşa sahip olan ve 15 Mart 2003 ile Mart 2006 tarihleri arasındaki periyotta travma nedeniyle hastaneye yatırılan kadınlar çalışmaya dahil edildi.

\section{BULGULAR}

Kadınlar (n=171) aynı yaş grubundaki bütün travma hastalarının (n=1809) \%9'unu kapsadı ve bunların \%29’u BAE ulusundandı. Kadınlar için ortalama yaş 30,5 yıl idi. Karayolu araç kazası (KAK), başlıca yaralanma nedeniydi $(\mathrm{n}=78$, \%46). Yanıklar, erkeklere göre kadınlarda anlamlı olarak daha yüksek bulundu ( $\mathrm{p}=0,001)$. Lomber kırıklar anlamlı şekilde erkeklerde daha yüksekti $(\mathrm{p}=0,03)$, servikal kırıklar anlamlı şekilde kadınlarda daha yüksekti $(\mathrm{p}=0,04)$. Kadınlarda pelvik kırıklar \%6,4, spinal kırıkları \%7 ve her iki yaralanmanın var olduğu \%1,2 oranında ki hastaya tanı konuldu, 3 kadın öldü $(\% 1,7)$; ölümlerin tümü KAK nedeniyle idi.

\section{SONUÇ}

Travmaya uğrayan kadınların çoğunluğu 20 ile 34 yaş arasındaydı. KAK, yaralanma ve ölümle ile ilgili başlıca nedendi. Kadınlarda travma, yüksek bir pelvik kırık insidansı ile birliktedir. Erkeklerdeki lomber yaralanmaların tersine, kadınlarda daha yüksek servikal yaralanma oranı gözlendi.

Anahtar Sözcükler: Kadın; çocuk doğurma çağı; travma.

\footnotetext{
Departments of ${ }^{1}$ Surgery, ${ }^{2}$ Obstetrics \& Gynecology, Faculty of Medicine and Health Sciences, United Arab Emirates (UAE) University,

Al-Ain District, Abu Dhabi, UAE; ${ }^{3}$ Department of Emergency Medicine, Tawam Hospital, Al-Ain, UAE.
}

Birleşik Arap Emirlikleri (BAE) Üniversitesi, Tıp ve Sağlık Bilimleri

Fakültesi, ${ }^{1}$ Cerrahi Anabilim Dalı, ${ }^{2}$ Kadın Hastalıkları ve

Doğum Anabilim Dalı, Al-Ain, Abu Dhabi, BAE;

${ }^{3}$ Tawam Hastanesi, Acil Tip Kliniği, Al-Ain, BAE. 
Trauma is a leading cause of death and disability worldwide. ${ }^{[1]}$ Females represent approximately onethird of the trauma patients presenting to the Emergency Department. ${ }^{[2]}$ Furthermore, road traffic collisions (RTCs) are one of the leading causes of trauma deaths in developing countries. ${ }^{[3]}$ More than half of all road traffic deaths occur among young adults aged 15-44 years. ${ }^{[3]}$ In the United Arab Emirates (UAE), RTC is the second cause of death in the nation. ${ }^{[4]}$ Female disability and death resulting from trauma have grave effects on the family and community. Few studies have been done on female trauma, and the majority were on pregnant women. Furthermore, trauma in females may involve the vertebrae and pelvis, with long-term morbidity, including urinary incontinence, pelvic organ prolapse, dyspareunia, infertility, and increased risk for operative delivery. ${ }^{[5,6]}$

Table 1. Profile of female trauma patients by nationality compared with males

\begin{tabular}{lcc}
\hline & $\begin{array}{c}\text { Female } \\
\text { Number (\%) }\end{array}$ & $\begin{array}{c}\text { Male } \\
\text { Number (\%) }\end{array}$ \\
\hline UAE & $50(29.2)$ & $198(12.1)^{*}$ \\
Arabs & $48(28.1)$ & $316(19.3)^{* *}$ \\
Indian subcontinent & $39(22.8)$ & $1058(64.6)^{* * *}$ \\
Others & $34(19.9)$ & $66(4)^{* * *}$ \\
Total & $171(100)$ & $1638(100)$ \\
\hline
\end{tabular}

${ }^{*} \mathrm{p}<0.0001 ; *{ }^{*} \mathrm{p}<0.008 ;{ }^{* * *} \mathrm{p}<0.0001 ;$ Fisher's exact test.

Table 2. Mechanism of injury of female trauma patients compared with males

\begin{tabular}{lcc}
\hline & $\begin{array}{c}\text { Female } \\
\text { Number (\%) }\end{array}$ & $\begin{array}{c}\text { Male } \\
\text { Number (\%) }\end{array}$ \\
\hline RTC & $78(45.6)$ & $613(37.4)^{*}$ \\
Fall & $42(24.6)$ & $138(8.4)^{* *}$ \\
Fall from height & $13(7.6)$ & $358(21.9)^{* *}$ \\
Burn & $18(10.5)$ & $69(4.2)^{* *}$ \\
Assault & $9(5.3)$ & $45(2.7)$ \\
Motorcycle/bicycle & $3(1.7)$ & $101(6.2)^{* * *}$ \\
Others & $8(4.7)$ & $314(19.2)$ \\
Total & $171(100)$ & $1638(100)$ \\
\hline
\end{tabular}

${ }^{*} \mathrm{p}<0.04,{ }^{* *} \mathrm{p}<0.001,{ }^{* * *} \mathrm{p}<0.01 ;$ Fisher's exact test.

Table 3. The level of spinal injury in female trauma patients compared to male patients

\begin{tabular}{lcc}
\hline & $\begin{array}{c}\text { Female }(\mathrm{n}=171) \\
\text { Number (\%) }\end{array}$ & $\begin{array}{c}\text { Male }(\mathrm{n}=1638) \\
\text { Number (\%) }\end{array}$ \\
\hline Cervical & $5(2.9)$ & $16(1.0)^{*}$ \\
Thoracic & $3(1.8)$ & $26(1.6)$ \\
Lumbar & $3(1.8)$ & $93(5.7)^{* *}$ \\
Multiple & $2(1.2)$ & $20(1.2)$ \\
Total & $13(7.6)$ & $155(9.5)$ \\
\hline
\end{tabular}

${ }^{*} \mathrm{p}<0.04 ;{ }^{* *} \mathrm{p}<0.03$; Fisher's exact test.
We aimed to study the incidence and nature of trauma in women of child-bearing age in the UAE.

\section{MATERIALS AND METHODS}

Data were collected from the Trauma Registry of Al-Ain Hospital. ${ }^{[7]} \mathrm{Al}$-Ain is the 4th largest city in the UAE, with a population of 463,000, and females represent $34.3 \%(n=160,000)$ of the population. ${ }^{[8]}$ Al-Ain Hospital, a highly specialized acute care and emergency hospital with 412 beds and 30 medical departments and divisions, is one of the two major hospitals in the Al-Ain District, Abu Dhabi. The Emergency Medicine and Trauma Centre handles 136,000 patients per year. ${ }^{[9]}$

The registry includes all patients hospitalized more than 24 hours in the hospital and those who died after arrival to the hospital. Females between 16-45 years (child-bearing age) admitted with trauma between 15 March 2003 and 15 March 2006 were selected. Data variables related to the patients' age, marital status, cause of injury, nature of injury, type of pelvic fracture, spinal injury, injury severity score (ISS), duration of stay, and outcome were recorded.

The Local Ethics Committee of Al-Ain Health District Area approved the data collection for all trauma patients who were admitted to Al-Ain Hospital or who died in the Emergency Department (Ethical approval NO: RECA/02/44).

\section{Statistics}

Unpaired t-test was used to compare continuous data between two independent groups and Fisher's exact test to compare categorical data between two independent groups.

\section{RESULTS}

A total number of 1809 patients were studied, of which 171/1809 (9\%) were females. The mean age for females was $30.5( \pm \mathrm{SD} 7.8)$ years compared with $31( \pm$ SD 7.7$)$ years in males. More than half $(53 \%$, $\mathrm{n}=92$ ) were in the age group of 20-34 years, while $23 \%(n=39)$ were in the age group 35-39 years. 95/171 $(55 \%)$ were married. Nearly one-third, 50/171 (29\%), were UAE nationals compared with $12.1 \%$ UAE nationals among males (Table 1).

In females, RTC was the cause of trauma in 78/171 (46\%) compared with $37.4 \%$ in males (Table 2). However, females were involved in $11.2 \%$ of all RTCs.

The ambulance was the method of arrival in $65 / 171(38 \%)$ patients. Of those, $86 \%$ were involved in RTC. Pelvic fracture was present in $11 / 171(6.4 \%)$ patients and spinal injury in $12(7 \%)$ patients, and two $(1.2 \%)$ had both pelvic fracture and spinal injury. $2.9 \%$ of the patients had cervical spine fractures, which was significantly higher than in males (Table 3 ). There was a total of $13 / 171(7.6 \%)$ patients with pelvic fractures: 
four $(2.3 \%)$ had unilateral pelvic fracture, two $(1.2 \%)$ had bilateral pelvic fracture and four $(2.3 \%)$ had open pelvic fracture. None was reported to have bladder or vaginal injury. There was no statistical difference in the ISS between males and females (median [range] ISS was 4 [1-41] for both groups). The mean hospital stay was $9.2( \pm$ SD 12.4) days.

There were three $(1.7 \%)$ deaths in the female group compared to $34(2.1 \%)$ deaths in the male group. This difference was not statistically significant. All deaths among females were due to RTCs, causing severe head injury with a low Glasgow Coma Scale $\leq 6$. The first patient was a 34-year-old woman who was admitted to the intensive care unit (ICU) with severe head injury associated with depressed skull fracture. She died six days after admission. The second patient was a 43-year-old woman who was admitted to the ICU with subdural hematoma, subarachnoid hemorrhage, brain stem contusion, and lower limb fractures. She died 14 days after admission to the ICU. The third patient was a 21-year-old woman who presented with a head injury, multiple rib fractures, retroperitoneal bleeding, open pelvic fracture, and fracture of the left femur. She died on the day of admission.

\section{DISCUSSION}

In our study, females aged 16-45 years represented $9 \%$ of the trauma patients. This is nearly half of that reported in other countries. ${ }^{[2,10]}$ Furthermore, it is higher than that observed in some of the neighboring countries with a similar socioeconomic pattern. ${ }^{[11]}$ Messahel et al. ${ }^{[12]}$ reported a ratio of 6.3:1 in Saudi Arabia. This can be explained by the demographic distribution of the Abu Dhabi Emirate, as females represent only one-third of the population. ${ }^{[4]}$

Trauma represented $21 \%$ of the annual mortality in Abu Dhabi Emirate in 2008. ${ }^{[4]}$ Interestingly, trauma among UAE national females was the highest (29.2\%) compared with other nationalities. In contrast, trauma among UAE males was the lowest (12.1\%) among the male patients. National females represent $72.3 \%$ of all females resident in the UAE, while male nationals represent $27.7 \%$ of the male population, which may explain these findings. ${ }^{[13]}$ In our study, the ratio of male to female was exceptionally high among patients from the Indian subcontinent. The reason for this might be that the majority of the labor workforce is mainly males from the Indian subcontinent. Male patients represent $98 \%$ of occupational-related injuries in Al-Ain, of which $74 \%$ are from the Indian subcontinent. ${ }^{[14]}$

Trauma was highest among females in the age group of 20-34 years. This is expected, as females in this age group are in their most active period. ${ }^{[15]}$

In our study, RTC was the main mechanism of in- jury in both females (45.6\%) and males (37.4\%). This high percentage reflects its magnitude in the UAE, as it is the main cause of death of all injuries in the UAE. Bener and Crandall ${ }^{[16]}$ have attributed this to careless driving and excessive speed. Furthermore, Barrs et al. ${ }^{[17]}$ showed a low compliance rate (11\%) for using seatbelts in Al-Ain city. Females represented $11.2 \%$ of all RTC patients in our study (Table 2). In comparison, Hamza et al. ${ }^{[18]}$ observed a similar percentage (14\%) among Bahraini females. Nevertheless, these figures are lower than those observed in other developing countries. This might be due to the low number of licensed female drivers. ${ }^{[18]}$ Most $(86 \%)$ of the RTC patients were transported by ambulance, which mainly reflects the severity of the injury.

Cervical spine fractures were significantly higher in females, while lumbar fractures were significantly higher in males. This might be due to the significantly higher incidence of cervical spine fractures with RTCs, while lumbar spine fractures were more common in accidental falls. ${ }^{[19]}$

There were no reported cases of vaginal or urinary tract injury (UTI) in the 13 cases of pelvic fracture. This might be due to the small number of patients with pelvic fractures. Another explanation might be that most were unilateral (stable) fractures of the pubic rami, which are unlikely to be associated with UTI. ${ }^{[20]}$ Furthermore, the reported incidence of UTI is generally low, ranging from $0.15 \%$ to $1.5 \% .{ }^{[21]}$ However, pelvic trauma may have serious and long-term effects on the female reproductive life. It seems that the longterm consequences of pelvic fracture are more common and severe. This is mainly due to the damage to the muscle, connective tissue, nerves, and blood supply of the pelvis resulting in neuropathy, pelvic floor dysfunction, and urogenital pain in nearly half of the females with pelvic fracture. ${ }^{[5]}$ Furthermore, about one-third of females suffer from sexual dysfunction. Sacral fractures are commonly associated with pelvic ring fractures and are associated with sacral root injuries. This might lead to bowel and bladder incontinence and sexual dysfunction. ${ }^{[22]}$ Trauma to the back and pelvis are associated with pelvic girdle pain. ${ }^{[23]}$ Unfortunately, we were unable to obtain long-term follow-up for these patients.

Surprisingly, there were no reported suicide attempts in our study. Haukka et al. ${ }^{[24]}$ reported the risk of suicide in Finland to be as high as $10 \%$, with a risk of repeated attempts of $30 \%$. The reported suicide rate in neighboring countries that are similar to the UAE is very low. Elfawal et al. ${ }^{[25]}$ reported a suicide rate of $1.1 / 100,000$ population per annum, with a male to female ratio of 4.5:1. Underreporting might be another cause for this low suicide rate. Furthermore, this study only included patients with trauma who were hospi- 
talized for more than 24 hours. Hence, patients with suicide attempts not requiring admission or who were discharged within 24 hours were not included in the results.

Road traffic collision (RTC) was the main cause of fatality in this study. The associated severe head injury and low Glasgow Coma Scale was an indicator of a significant increased risk of mortality. ${ }^{[26]}$ Therefore, it is unlikely that alternative management would have altered the outcome.

In conclusion, the majority of females involved in trauma were 20-34 years old. RTC is the main mechanism for injury and fatality. Female trauma is associated with a high incidence of pelvic fractures. Pelvic fractures are not necessarily associated with bladder or vaginal injuries. A higher rate of cervical injuries was observed in females in contrast to lumbar injuries in males.

\section{REFERENCES}

1. Sasser SM, Varghese M, Joshipura M, Kellermann A. Preventing death and disability through the timely provision of prehospital trauma care. Bull World Health Organ 2006;84:507.

2. Chan KC, Seow K, Lau G, Chan SP, Tham KY. Female trauma patients in the emergency department: should their injury prevention programme be different? Hong Kong J Emerg Med 2003;10:13-8.

3. Peden M, Scurfield R, Sleet D, Mohan D, Hayder AA, Jarwan $\mathrm{E}$, et al. World report on road traffic injury prevention. Geneva: World Health Organization; 2004.

4. Health Authority Abu Dhabi (HAAD). Health Statistics 2008 Quarter 2. 2009. Available at http://bit.ly/K7y8QK. Accessed on 10 April 2012.

5. Baessler K, Bircher MD, Stanton SL. Pelvic floor dysfunction in women after pelvic trauma. BJOG 2004;111:499-502.

6. Kammerer-Doak D. Assessment of sexual function in women with pelvic floor dysfunction. Int Urogynecol J Pelvic Floor Dysfunct 2009;20:45-50.

7. Shaban S, Ashour M, Bashir M, El-Ashaal Y, Branicki F, Abu-Zidan FM. The long term effects of early analysis of a trauma registry. World J Emerg Surg 2009;4:42.

8. Annual Report. Preventive Medicine Sector, Ministry of Health, United Arab Emirates, 2006. Published on November 2007.

9. Alain hospital website. Available at http://bit.ly/IPAQOn. Accessed on 10 April 2012.

10. Laflamme L, Eilert-Petersson E. Injury risks and socioeconomic groups in different settings. Differences in morbidity between men and between women at working ages. Eur J Public Health 2001;11:309-13.

11. Karbakhsh M, Zandi NS, Rouzrokh M, Zarei MR. Injury epidemiology in Kermanshah: the National Trauma Project in Islamic Republic of Iran. East Mediterr Health J 2009; 15:5764.

12. Messahel F, Seraj M, al-Qasabi Q, el-Bakry AK. Trauma cases admitted to the surgical intensive care unit--progress and outcome. Middle East J Anesthesiol 1996;13:585-91.

13. Emiratesfreezones, UAE population, http://www.emiratesfreezone.com. Accessed on 10 April 2012.

14. Barss P, Addley K, Grivna M, Stanculescu C, Abu-Zidan F. Occupational injury in the United Arab Emirates: epidemiology and prevention. Occup Med (Lond) 2009;59:493-8.

15. Nilambar J, Agrawal SC. Epidemiological study of road traffic accident cases: a study from Eastern Nepal, Regional Health Forum WHO South-East Asia Region 2004;8:15-22.

16. Bener A, Crandall D. Road traffic accidents in the United Arab Emirates compared to western countries. Adv Transport Stud Int J 2005;6:5-12.

17. Barss P, Al-Obthani M, Al-Hammadi A, Al-Shamsi H, El-Sa$\operatorname{dig}$ M, Grivna M. Prevalence and issues in non-use of safety belts and child restraints in a high-income developing country: lessons for the future. Traffic Inj Prev 2008;9:256-63.

18. Hamza AY, Al-Mousawi FR, Husel-Pincock A. Road Traffic Accidents in Bahrain. Bahrain Medical Bulletin 2003; 25 Available at: http://bit.ly/JHsbtJ. Accessed on 10 April 2012.

19. Heidari P, Zarei MR, Rasouli MR, Vaccaro AR, RahimiMovaghar V. Spinal fractures resulting from traumatic injuries. Chin J Traumatol 2010;13:3-9.

20. Koraitim MM, Marzouk ME, Atta MA, Orabi SS. Risk factors and mechanism of urethral injury in pelvic fractures. $\mathrm{Br}$ J Urol 1996;77:876-80.

21. Bariol SV, Stewart GD, Smith RD, McKeown DW, Tolley DA. An analysis of urinary tract trauma in Scotland: imnpact on management and resource needs. Surgeon 2005;3:27-30.

22. Russell GV, Jarrett CA, Routt MC. 2009. Pelvic Fractures. Website: http://bit.ly/K57HNW. Accessed on: 10 April 2012.

23. Albert HB, Godskesen M, Korsholm L, Westergaard JG. Risk factors in developing pregnancy-related pelvic girdle pain. Acta Obstet Gynecol Scand 2006;85:539-44.

24. Haukka J, Suominen K, Partonen T, Lönnqvist J. Determinants and outcomes of serious attempted suicide: a nationwide study in Finland, 1996-2003. Am J Epidemiol 2008;167:1155-63.

25. Elfawal MA. Cultural influence on the incidence and choice of method of suicide in Saudi Arabia. Am J Forensic Med Pathol 1999;20:163-8.

26. Eid HO, Barss P, Adam SH, Torab FC, Lunsjo K, Grivna M, et al. Factors affecting anatomical region of injury, severity, and mortality for road trauma in a high-income developing country: lessons for prevention. Injury 2009;40:703-7. 